\title{
Pengaruh Motivasi, Lingkungan Keluarga, Biaya Pendidikan pada Minat Mahasiswa Mengikuti Pendidikan Profesi Akuntansi
}

\author{
Ida Ayu Ardhia Paramesti Ningrat ${ }^{1}$ \\ Fakultas Ekonomi dan Bisnis \\ Universitas Udayana, Indonesia \\ Email: idaayuardiapn@gmail.com
}

\author{
Luh Gede Krisna Dewi2 \\ Fakultas Ekonomi dan Bisnis \\ Universitas Udayana, Indonesia
}

\begin{abstract}
ABSTRAK
Prodi Akuntansi selalu mengalami banyak perkembangan yang terus menerus, tetapi masih sedikit mahasiswa yang berminat untuk melanjutkan ke Pendidikan Profesi Akuntansi. Penelitian bertujuan menguji pengaruh motivasi karir, motivasi ekonomi, lingkungan keluarga, dan persepsi biaya pendidikan pada minat mahasiswa akuntansi mengikuti Pendidikan Profesi Akuntansi. Penelitian dilakukan di Fakultas Ekonomi dan Bisnis Universitas Udayana. Sampel adalah mahasiswa akuntansi angkatan 2016 program regular sebanyak 181 responden dengan simple random sampling. Data dikumpulkan dengan kuisioner dan dianalisis dengan analisis regresi linier berganda. Berdasarkan hasil analisis diketahui motivasi karir, motivasi ekonomi, lingkungan keluarga, dan persepsi biaya pendidikan berpengaruh positif pada minat mahasiswa mengikuti Pendidikan Profesi Akuntansi.
\end{abstract}

Kata Kunci: Motivasi Karir; Motivasi Ekonomi; Lingkungan Keluarga; Persepsi Biaya Pendidikan.

\section{Influence Of Motivation, Family Environment, Educational Costs On Students' Interest In Attending Accounting Profession Education}

\begin{abstract}
Accounting Study Program experiences continuous development, but there are only a few students who are interested in continuing into Professional Accounting Education. The research aims to examine the influence of career motivation, economic motivation, family environment, and perceptions of educational costs on students' interest to study at Accounting Professional Education. Study conducted at the Faculty of Economics and Business, Udayana University. The sample are students at accounting regular program class of 2016, with 181 respondents using simple random sampling. Data collected by questionnaire and analyzed by multiple linear regression. Based on the results, career motivation, economic motivation, family environment, and perceptions of educational costs have a positive effect on student interest in taking the Accounting Professional Education.
\end{abstract}

Keywords: Career Motivation; Economic Motivation; Family Environment; Perceived Education Costs.

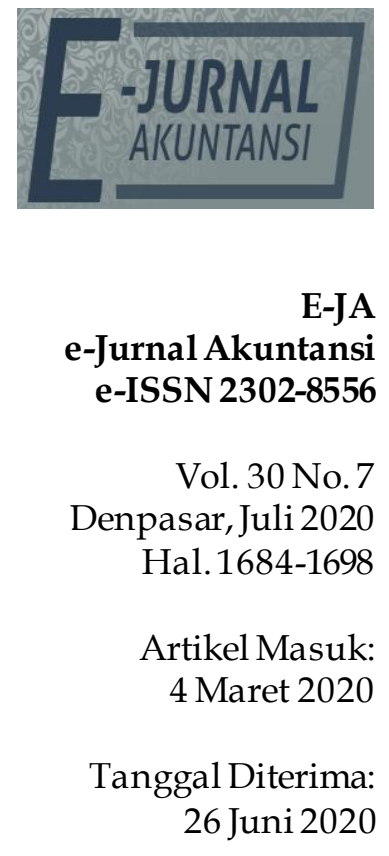

The Article is Available in: https://ojs.unud.ac.id/index.php/Akuntansi/index 


\section{PENDAHULUAN}

Akuntansi merupakan salah satu jurusan di Fakultas Ekonomi yang sangat diminati oleh mahasiswa (Aryani \& Erawati, 2016). Setiap tahun peminat jurusan akuntansi di berbagai Universitas mengalami peningkatan sehingga lulusan tiap tahun menjadi semakin banyak dan persaingan dalam memperoleh pekerjaan tidak dapat dihindari lagi (Dewi \& Ratnadi, 2018). Rata-rata mahasiswa memilih jurusan akuntansi dilandasi oleh keinginan untuk menjadi profesional di bidang akuntansi (Ikbal, 2015).

Pendidikan Profesi Akuntansi (PPAk) merupakan jenjang pendidikan tambahan yang ditujukan bagi seorang lulusan sarjana ekonomi jurusan akuntansi yang ingin mendapatkan gelar Akuntan. Suatu profesi memiliki syarat agar dapat menjadi seseorang yang ahli di bidangnya dan bekerja secara profesional. Pendidikan Profesi Akuntansi (PPAk) penting bagi mahasiswa jurusan akuntansi, sebab PPAk dapat meningkatkan kompetensi seseorang agar menjadi seorang akuntan yang profesional. Tujuan dari program pendidikan profesi akuntansi adalah menghasilkan lulusan akuntan yang menguasai keahlian dibidang profesi akuntan. Dengan demikian, lulusan PPAk nantinya akan memiliki daya saing sebagai akuntan yang lebih tinggi dibandingkan dengan sarjana ekonomi dari jurusan akuntansi yang tidak mempunyai predikat akuntan.

Data yang ditampilkan pada Tabel 1, menjelaskan bahwa jumlah mahasiswa yang mendaftar PPAk pada tahun akademik 2015-2019 angkatan XXI-XXX mengalami naik turun atau fluktuatif jumlah mahasiswa mendaftar dan jumlah mahasiswa diterima. Hal tersebut menunjukkan bahwa minat mahasiswa akuntansi khususnya dari Universitas Udayana terhadap mengikuti pendidikan profesi akuntansi relatif masih rendah. Melihat rendahnya minat mahasiswa akuntansi maka untuk meningkatkan profesionalisme ditengah tingginya kebutuhan dan tuntutan peningkatan pekerjaan diperlukan pengetahuan dari dalam diri mahasiswa terhadap minat untuk mengikuti PPAk agar dapat meningkatkan kemampuan di bidang Akuntansi (Sapitri \& Yaya, 2015).

Tabel 1. Perkembangan Jumlah Mahasiswa PPAk FEB UNUD tahun 2015-2019

\begin{tabular}{cccc}
\hline $\begin{array}{c}\text { Tahun } \\
\text { Akademik }\end{array}$ & Angkatan & $\begin{array}{c}\text { Jumlah Mahasiswa } \\
\text { Mendaftar }\end{array}$ & $\begin{array}{c}\text { Jumlah Mahasiswa } \\
\text { diterima }\end{array}$ \\
\hline 2015 & XXI & 27 & 26 \\
& XXII & 26 & 24 \\
2016 & XXIII & 28 & 24 \\
& XXIV & 11 & 9 \\
2017 & XXV & 18 & 18 \\
& XXVI & 15 & 14 \\
2018 & XXVII & 17 & 16 \\
& XXVIII & 20 & 19 \\
2019 & XXIX & 25 & 25 \\
& XXX & 16 & 15
\end{tabular}

Sumber: PPAK FEB Unud, 2019

Profesi akuntansi mempunyai hubungan erat dengan tata nilai dan budaya yang berkembang bukan hanya dilingkungan bisnis tetapi dikalangan untuk 
masyarakat (Dos Santos \& De Almeida, 2018). Sarjana akuntansi dengan sertfikasi profesi akuntansi akan semakin berpeluang meniti karir sebagai auditor pemerintahan, auditor internal, akuntan sektor publik, akuntan manajemen, akuntan pendidik, akuntan perpajakan, akuntan keuangan, maupun akuntan sistem informasi (Khomsiyah \& Lindrianasari, 2017)

Berdasarkan penelitian Dyastari \& Yadnyana (2016), Vesperalis \& Muliartha (2017), serta Bagus \& Marta (2018) menemukan hasil bahwa banyak faktor yang mempengaruhi minat mahasiswa untuk mengikuti PPAk seperti sikap, motivasi karir, motivasi ekonomi, motivasi sosial, motivasi kualitas, motivasi gelar, biaya pendidikan, dan lama pendidikan. Berdasarkan faktorfaktor tersebut, penelitian ini meneliti beberapa faktor yang mendorong minat mahasiswa dalam mengikuti pendidikan profesi akuntansi, faktor tersebut adalah motivasi karir, motivasi ekonomi, dorongan dari lingkungan keluarga, serta persepsi mengenai biaya pendidikan dalam mengikuti pendidikan profesi akuntansi. Faktor-faktor tersebut dipilih karena pentingnya peran motivasi terhadap minat mahasiswa untuk mencapai tujuan menjadi akuntan profesional dalam mengikuti PPAk, serta dorongan dari lingkungan keluarga terhadap mahasiswa dalam perkembangan pemilihan karir ataupun melanjutkan pendidikan, dan persepsi biaya pendidikan agar mahasiswa tidak hanya menilai dari biaya pendidikan yang dikeluarkannya saja akan tetapi manfaat apa yang akan di dapat dalam mengikuti PPAk.

Motivasi karir merupakan dorongan yang timbul dari dalam diri seseorang untuk meningkatkan kemampuan pribadinya dan dalam rangka mencapai kedudukan, jabatan atau karir yang lebih baik dari sebelumnya (Sojow et al., 2018). Penelitian yang dilakukan oleh Dyastari \& Yadnyana (2016), Vesperalis \& Muliartha (2017), serta Bagus \& Marta (2018) menunjukan bahwa motivasi karir berpengaruh positif pada minat mahasiswa mengikuti pendidikan profesi akuntansi. Artinya semakin kuat motivasi mahasiswa dalam meningkatkan kemampuan pribadi dalam memperoleh karir yang baik, maka semakin tinggi minat mahasiswa dalam mengikuti Pendidikan Profesi Akuntansi.

Motivasi ekonomi merupakan dorongan yang timbul dari dalam diri seseorang untuk meningkatkan kebutuhan financial atau keuangan. Orangorang yang termotivasi secara ekonomis akan mampu mengevaluasi standar hidup mereka dengan menggunakan kemampuan sesuai dengan konteks citacita yang sudah ditetapkan berdasarkan standar hidup mereka (Sigry et al., 2015). Dampak implementasi kebijakan yang terkait dengan menunjukkan bahwa pendidikan dapat dipengaruhi oleh beberapa faktor, salah satunya adalah faktor ekonomi (Chaudhary, 2015). Penelitian yang dilakukan oleh Berlinasari \& Erawati (2017), Bagus \& Marta (2018) menunjukkan bahwa motivasi ekenomi berpengaruh positif pada minat mahasiwa mengikuti pendidikan profesi akuntansi. Artinya semakin kuat dorongan motivasi ekonomi mahasiswa untuk mencapai penghargaan finansial yang diinginkan maka semakin tinggi minat mahasiswa mengikuti Pendidikan Profesi Akuntansi.

Lingkungan keluarga merupakan lingkungan pertama dan utama yang mempengaruhi perkembangan dan tingkah laku anak. Dukungan orangtua 
sangat penting untuk mendorong anaknya dalam memilih masa depan yang diinginkan seperti memilih pekerjaan (Giantari \& Ramantha, 2019). Berdasarkan penelitian yang dilakukan oleh Dibabe et al. (2015), Kurniawan et al. (2018), Hsiao \& De Castro Casa Nova (2016), Li \& Qiu (2018) menunjukkan bahwa lingkungan keluarga berpengaruh positif pada minat mahasiwa mengikuti pendidikan profesi akuntansi. Artinya semakin besar dukungan dari lingkungan keluarga kepada mahasiswa maka semakin tinggi minat untuk mengikuti Pendidikan Profesi Akuntansi.

Persepsi biaya pendidikan merupakan sebuah proses saat individu mengatur dan menginterpretasikan kesan-kesan sensoris mereka terhadap keseluruhan pengorbanan finansial yang dikeluarkan oleh mahasiswa untuk keperluan selama menempuh pendidikan dari awal sampai berakhirnya pendidikan. Berdasarkan penelitian yang dilakukan oleh Dewi \& Ratnadi (2018), Made et al. (2020), Park et al. (2019), Abdul Aziz et al. (2017), Mbawuni \& Nimako (2015), Rosyadi (2018) persepsi biaya pendidikan berpengaruh positif pada minat mahasiswa mengikuti pendidikan profesi akuntansi. Artinya semakin tinggi persepsi positif mengenai cara pandang terhadap biaya pendidikan yang dikeluarkan oleh mahasiswa maka akan timbul minat mahasiswa mengikuti Pendidikan Profesi Akuntansi.

Karir adalah suatu pilihan yang berasal dari dalam diri seseorang untuk melakukan sebuah usaha yang dapat dikatakan bahwa motivasi karir adalah dorongan untuk mencapai keunggulan karir, meningkatkan keterampilan serta keahlian dalam berkarir, dan mengembangkan kreatifitas dalam hal baru (inovatif). Penelitian yang dilakukan oleh Baliyan \& Baliyan (2016) menyatakan bahwa mahasiswa akuntansi yang memilih karir sebagai akuntan publik mengharapkan keamanan kerja, kepuasan kerja, keahlian akuntansi dan penghasilan di masa mendatang yang potensial.

Pendidikan profesi Akuntansi merupakan institusi pendidikan yang memiliki pengaruh besar pada perkembangan karir seseorang akuntan. Pendidikan profesi akuntansi juga memberikan kontribusi positif bagi mahasiswa yang ingin mengembangkan keahlian dan kemampuannya di bidang akuntansi. Seseorang yang ingin memiliki motivasi karir yang tinggi di masa depan, dapat meningkatkan minatnya untuk mengikuti pendidikan profesi akuntansi. Penelitian dari Berlinasari \& Erawati (2017), serta Bagus \& Marta (2018) menunjukkan bahwa motivasi karir berpengaruh positif pada minat mahasiswa mengikuti pendidikan profesi akuntansi. Berdasarkan uraian diatas, dapat dikatakan bahwa semakin tinggi pengaruh motivasi karir, maka semakin tinggi pula minat mahasiswa untuk mengikuti pendidikan profesi akuntansi. Jadi hipotesis yang dapat dikembangkan berdasarkan hal tersebut adalah sebagai berikut:

$\mathrm{H}_{1}$ : Motivasi karir berpengaruh positif pada minat mahasiswa mengikuti pendidikan profesi akuntansi.

Teori motivasi Maslow menjelaskan bahwa setiap individu mempunyai beraneka ragam kebutuhan yang dapat mempengaruhi perilaku mereka. Motivasi dorongan yang timbul dalam diri seseorang untuk meningkatkan kemampuan pribadinya dalam rangka untuk mencapai penghargaan finansial yang diinginkan (Rybnicek et al., 2019). Adanya motivasi ekonomi disebabkan 
tuntutan dalam memenuhi kebutuhan fisiologis, kebutuhan rasa aman, kebutuhan sosial, kebutuhan akan penghargaan dan kebutuhan akan aktualisasi diri. Secara umum penghargaan finansial terdiri dari penghargaan langsung (gaji pokok, pembagian dari laba) dan penghargaan tidak langsung (asuransi, tunjangan, program pensiun). Penelitian yang dilakukan oleh oleh Berlinasari \& Erawati (2017), serta Bagus \& Marta (2018) menunjukkan bahwa motivasi ekenomi berpengaruh positif pada minat mahasiwa mengikuti pendidikan profesi akuntansi. Berdasarkan uraian diatas, dapat dikatakan bahwa semakin tinggi pengaruh motivasi ekonomi, maka semakin tinggi pula minat mahasiswa untuk mengikuti pendidikan profesi akuntansi. Jadi hipotesis yang dapat dikembangkan berdasarkan hal tersebut adalah sebagai berikut:

$\mathrm{H}_{2}$ : Motivasi ekonomi berpengaruh positif pada minat mahasiswa mengikuti pendidikan profesi akuntansi.

Keluarga memegang peranan penting dalam memberikan pandangan mengenai nilai-nilai dalam memilih pekerjaan. Dengan nilai-nilai yang telah diterima dari keluarga akan memunculkan minat dan pandangan seseorang terhadap profesi. Penelitian yang dilakukan oleh Dibabe et al. (2015), Kurniawan et al. (2018), Hsiao \& De Castro Casa Nova (2016), Li \& Qiu (2018) menunjukkan bahwa lingkungan keluarga berpengaruh positif pada minat mahasiwa mengikuti pendidikan profesi akuntansi. Berdasarkan uraian diatas, dapat dikatakan bahwa semakin tinggi pengaruh lingkungan keluarga, maka semakin tinggi pula minat mahasiswa untuk mengikuti pendidikan profesi akuntansi. Jadi hipotesis yang dapat dikembangkan berdasarkan hal tersebut adalah sebagai berikut:

$\mathrm{H}_{3}$ : Lingkungan keluarga berpengaruh positif pada minat mahasiswa mengikuti pendidikan profesi akuntansi.

Persepsi biaya pendidikan merupakan cara pandang mahasiswa terhadap biaya yang dikeluarkan oleh mahasiswa untuk keperluan selama menempuh pendidikan dari awal sampai berakhirnya pendidikan. Biaya pendidikan dikeluarkan untuk mendapatkan manfaat di masa yang akan datang. Hal inilah yang menyebabkan dalam mengeluarkan biaya diperlukan analisis biaya manfaat (Aryani \& Erawati, 2016). Penelitan yang dilakukan oleh Dewi \& Ratnadi (2018) persepsi biaya pendidikan berpengaruh positif pada minat mahasiswa mengikuti pendidikan profesi akuntansi. Berdasarkan uraian diatas, dapat dikatakan bahwa semakin tinggi persepsi positif mengenai biaya pendidikan, maka semakin tinggi pula minat mahasiswa untuk mengikuti pendidikan profesi akuntansi. Jadi hipotesis yang dapat dikembangkan berdasarkan hal tersebut adalah sebagai berikut:

$\mathrm{H}_{4}$ : Persepsi biaya pendidikan berpengaruh positif pada minat mahasiswa mengikuti pendidikan profesi akuntansi.

\section{METODE PENELITIAN}

Desain penelitian yang digunakan dalam penelitian ini adalah pendekatan kuantitatif yang berbentuk asosiatif. Penelitian ini dilakukan di Fakultas Ekonomi dan Bisnis Universitas Udayana. Alasan dipilihnya lokasi penelitian karena penelitian ini meneliti minat mahasiswa akuntansi angkatan 2016, 
karena sebagian besar mahasiswa yang mengikuti PPAk Universitas Udayana berasal dari Fakultas Ekonomi dan Bisnis Universitas Udayana. Obyek pada penelitian ini adalah minat melanjutkan atau mengikuti PPAk mahasiswa akuntansi di Fakultas Ekonomi dan Bisnis Universitas Udayana angkatan 2016. Angkatan 2016 dipilih karena merupakan angkatan yang telah menempuh semua mata kuliah.

Motivasi karir adalah dorongan untuk mencapai keunggulan karir, meningkatkan keterampilan serta keahlian dalam berkarir, dan mengembangkan kreatifitas dalam hal baru (inovatif). Motivasi ekonomi merupakan dorongan yang timbul dalam diri seseorang untuk meningkatkan kemampuan pribadinya dalam rangka untuk mencapai penghargaan finansial yang diinginkan. Lingkungan keluarga merupakan peran yang sangat besar untuk mendukung memilih masa depan dalam perkembangan dan pemilihan karir atau pekerjaan. Persepsi biaya pendidikan merupakan sebuah proses mengatur dan menginterpretasikan biaya-biaya pendidikan yang digunakan untuk menunjang perkuliahan. Minat Mahasiswa mengikuti Pendidikan Profesi Akuntansi adalah kecenderungan hati yang tinggi terhadap sesuatu hal, hal dalam pengertian ini berarti kegairahan dan kecenderungan hati untuk mengikuti PPAk.

Populasi dalam penelitian ini adalah seluruh mahasiswa S1 angkatan 2016 akuntansi reguler Bukit dan reguler Denpasar Fakultas Ekonomi dan Bisnis, Universitas Udayana. Teknik pengumpulan sampel yang digunakan adalah metode simple random sampling. Jumlah sampel yang akan diteliti adalah sebanyak 181 orang. Teknik pengumpulan data yang digunakan dalam penelitian ini adalah kuesioner

\section{HASIL DAN PEMBAHASAN}

Data penelitian dikumpulkan dengan menyebarkan kuesioner dengan cara memberikan pernyataan kuesioner secara online dengan menggunakan Google form kepada mahasiswa akuntansi angkatan 2016 Fakultas Ekonomi dan Bisnis Universitas Udayana di Bali. Penyebaran kuesioner dimulai 29 November sampai dengan 5 Desember 2019. Kuesioner yang disebar oleh peneliti sebanyak 250 kuesioner dengan tingkat pengembalian responden 73 persen.

Tabel 2. Karakteristik Responden

\begin{tabular}{clcc}
\hline No & \multicolumn{1}{c}{ Keterangan } & Jumlah & Presentase $(\%)$ \\
\hline 1 & Jenis Kelamin & 55 & \\
& Laki - laki & 126 & $30,2 \%$ \\
& Perempuan & 181 & $69,8 \%$ \\
& Total & & $100 \%$ \\
2 & Program & 69 & $37,9 \%$ \\
& Reguler Pagi & 112 & $62,1 \%$ \\
& Reguler Sore & 181 & $100 \%$ \\
\hline
\end{tabular}

Sumber: Data Penelitian, 2019 
Data Jenis kelamin menunjukkan frekuensi dan persentase responden berdasarkan jenis kelamin. Responden yang berjenis kelamin laki-laki adalah 55 orang dengan persentase 30,2 persen, sedangkan responden yang berjenis kelamin perempuan adalah 126 orang dengan persentase 69,8 persen. Responden ini di dominasi oleh responden yang berjenis kelamin perempuan. Data Program menunjukkan frekuensi dan persentase responden berdasarkan program kelas. Responden dari regular pagi adalah 69 orang dengan persentase $37,9 \%$, sedangkan responden dari regular sore adalah 112 orang dengan persentase $62,1 \%$. Responden ini di dominasi oleh responden regular sore.

Tabel 3. Hasil Uji Validitas

\begin{tabular}{|c|c|c|}
\hline Variabel & Indikator & Pearson Correlation \\
\hline \multirow{5}{*}{$\begin{array}{c}\text { Motivasi Karir } \\
\qquad\left(\mathrm{X}_{1}\right)\end{array}$} & X1.1 & 0,888 \\
\hline & $\mathrm{X} 1.2$ & 0,702 \\
\hline & $\mathrm{X} 1.3$ & 0,928 \\
\hline & $\mathrm{X} 1.4$ & 0,824 \\
\hline & X1.5 & 0,848 \\
\hline \multirow{4}{*}{$\begin{array}{l}\text { Motivasi Ekonomi } \\
\qquad\left(\mathrm{X}_{2}\right)\end{array}$} & X1.6 & 0,720 \\
\hline & $\begin{array}{l}X 1.7 \\
X 2.1\end{array}$ & $\begin{array}{l}0,634 \\
0,818\end{array}$ \\
\hline & $\mathrm{X} 2.2$ & 0,865 \\
\hline & $X 2.3$ & 0,920 \\
\hline \multirow{5}{*}{$\begin{array}{l}\text { Lingkungan Keluarga } \\
\qquad\left(X_{3}\right)\end{array}$} & $\mathrm{X} 2.4$ & 0,883 \\
\hline & $X 2.5$ & 0,881 \\
\hline & $X 2.6$ & 0,830 \\
\hline & $\mathrm{X} 2.7$ & 0,815 \\
\hline & X3.1 & 0,942 \\
\hline \multirow{5}{*}{$\begin{array}{l}\text { Persepsi Biaya } \\
\text { Pendidikan } \\
\left(X_{4}\right)\end{array}$} & $\mathrm{X} 3.2$ & 0,845 \\
\hline & X3.3 & 0,883 \\
\hline & X3.4 & 0,752 \\
\hline & $X 4.1$ & 0,938 \\
\hline & X4.2 & 0,939 \\
\hline \multirow{7}{*}{$\begin{array}{l}\text { Minat Mahasiswa } \\
\text { Mengikuti PPAk } \\
(\mathrm{Y})\end{array}$} & $X 4.3$ & 0,896 \\
\hline & X4.4 & 0,867 \\
\hline & $X 4.5$ & 0,937 \\
\hline & Y.1 & 0,939 \\
\hline & Y.2 & 0,939 \\
\hline & Y.3 & 0,939 \\
\hline & Y.4 & 0,937 \\
\hline
\end{tabular}

Sumber: Data Penelitian, 2019

Hasil uji validitas instrumen penelitian disajikan pada Tabel 3, yang menunjukkan bahwa seluruh indikator dalam variabel penelitian (motivasi karir, motivasi ekonomi, lingkungan keluarga, persepsi biaya pendidikan, dan minat mahasiswa mengikuti PPAk) memiliki nilai Pearson Correlation yang lebih besar 
dari angka 0,30 sehingga seluruh indikator tersebut dikatakan telah memenuhi syarat validitas data.

Tabel 4. Hasil Uji Reliabilitas

\begin{tabular}{lc}
\hline \multicolumn{1}{c}{ Variabel } & Cronbach's Alpha \\
\hline Motivasi Karir $\left(\mathrm{X}_{1}\right)$ & 0,892 \\
Motivasi Ekonomi $\left(\mathrm{X}_{2}\right)$ & 0,936 \\
Lingkungan Keluarga $\left(\mathrm{X}_{3}\right)$ & 0,872 \\
Persepsi Biaya Pendidikan $\left(\mathrm{X}_{4}\right)$ & 0,952 \\
Minat Mahasiswa Mengikuti PPAk $(\mathrm{Y})$ & 0,955 \\
\hline
\end{tabular}

Sumber: Data Penelitian, 2019

Suatu instrumen dikatakan reliabel, jika instrumen tersebut memiliki nilai Alpha Cronbach lebih dari 0,70. Hasil uji reliabilitas menunjukkan bahwa setiap variabel memiliki nilai koefisien Alpha Cronbach lebih dari 0,70. Hal ini dapat dikatakan bahwa semua variabel dalam penelitian ini adalah reliabel.

Tabel 5. Hasil Statistik Deskriptif

\begin{tabular}{lccccc}
\hline Variabel & N & Minimum & Maximum & Mean & $\begin{array}{c}\text { Std. } \\
\text { Deviation }\end{array}$ \\
\hline Motivasi Karir & 181 & 16 & 28 & 23,50 & 3,078 \\
Motivasi Ekonomi & 181 & 14 & 28 & 23,87 & 3,073 \\
Lingkungan Keluarga & 181 & 8 & 16 & 13,71 & 1,698 \\
$\begin{array}{l}\text { Persepsi Biaya } \\
\text { Pendidikan }\end{array}$ & 181 & 8 & 20 & 15,87 & 2,937 \\
$\begin{array}{l}\text { MinatMengikuti } \\
\text { PPAk }\end{array}$ & 181 & 9 & 16 & 13,79 & 1,764 \\
\hline
\end{tabular}

Sumber: Data Penelitian, 2019

Variabel motivasi karir $\left(X_{1}\right)$ mempunyai nilai minimum sebesar 16 , dan nilai maksimum sebesar 28 dengan nilai rata-rata sebesar 23,50 yang diukur dengan 7 item pernyataan yang menghasilkan nilai sebesar 3,35, Hal ini berarti rata-rata responden memberikan skor 3 pada setiap item pernyataan pada variabel motivasi karir. Standar deviasi pada variabel motivasi karir sebesar 3,078. Sebagian besar menyetujui pertanyaan-pertanyaan yang diajukan dalam kusioner, sehingga motivasi karir dapat berperan dalam mencapai keunggulan berkarir.

Variabel motivasi ekonomi $\left(\mathrm{X}_{2}\right)$ mempunyai nilai minimum sebesar 14 dan nilai maksimum sebesar 28 dengan nilai rata-rata sebesar 23,87 yang diukur dengan 7 item pernyataan yang menghasilkan nilai sebesar 3,41, Hal ini berarti rata-rata responden memberikan skor 3 pada setiap item pernyataan pada variabel motivasi ekonomi. Deviasi standar pada motivasi ekonomi sebesar 3,073. Sebagian besar menyetujui pertanyaan-pertanyaan yang diajukan dalam kusioner, sehingga motivasi ekonomi dapat berperan dalam meningkatkan penghargaan finansial.

Variabel lingkungan keluarga $\left(X_{3}\right)$ mempunyai nilai minimum sebesar 8 dan nilai maksimum sebesar 16 dengan nilai rata-rata sebesar 13,71 yang diukur dengan 4 item pernyataan yang menghasilkan nilai sebesar 3,42, hal ini berarti rata-rata responden memberikan skor 3 pada setiap item pernyataan pada ariabel lingkungan keluarga. Deviasi standar pada lingkungan keluarga sebesar 1,689. Sebagian besar menyetujui pertanyaan- 
pertanyaan yang diajukan dalam kusioner, sehingga lingkungan kelurga dapat berperan dalam memilih masa depan dalam bekerja.

Variabel persepsi biaya pendidikan $\left(X_{4}\right)$ mempunyai nilai minimum sebesar 8 dan nilai maksimum sebesar 20 dengan nilai rata-rata sebesar 15,87 yang diukur dengan 5 item pernyataan yang menghasilkan nilai sebesar 3,2, hal ini berarti rata-rata responden memberikan skor 3 pada setiap item pernyataan pada variabel persepsi biaya pendidikan. Deviasi standar pada persepsi biaya pendidikan sebesar 2,937. Sebagian besar menyetujui pertanyaan-pertanyaan yang diajukan dalam kusioner, sehingga biaya pendidikan dapat berperan dalam proses mengatur biaya yang digunakan untuk menunjang perkuliahan.

Variabel minat mengikuti PPAk (Y) mempunyai nilai minimum sebesar 9 dan nilai maksimum sebesar 16 dengan nilai rata-rata sebesar 13,79 yang diukur dengan 4 item pernyataan yang menghasilkan nilai sebesar 3,44, hal ini berarti rata-rata responden memberikan skor 3 pada setiap item pernyataan pada variabel minat mengikuti. Sebagian besar menyetujui pertanyaanpertanyaan yang diajukan dalam kusioner, sehingga minat mengikuti PPAk dapat berperan dalam mencapai gelar akuntan secara profesional.

Tabel 6. Hasil Uji Normalitas

\begin{tabular}{lll}
\hline & & Unstandardized Residual \\
\hline $\mathrm{N}$ & 181 & \\
Kolmogorov-Smirnov Z & 0,889 & \\
Asymp. Sig. (2-tailed) & 0,408 & \\
\hline
\end{tabular}

Sumber: Data Penelitian, 2019

Pada Tabel 6, menunjukkan bahwa nilai Kolmogorov-Smirnov Z sebesar 0,889, sedangkan Asymp. Sig. (2-tailed) sebesar 0,408. Hasil tersebut mengindikasikan bahwa model persamaan regresi tersebut berdistribusi secara normal.

Tabel 7. Hasil Uji Multikolinearitas

\begin{tabular}{lcc}
\hline \multicolumn{1}{c}{ Model } & \multicolumn{2}{c}{ Colinearity Statistic } \\
\cline { 2 - 3 } & Tolerance & VIF \\
\hline Motivasi Karir $\left(\mathrm{X}_{1}\right)$ & 0,477 & 2,098 \\
Motivasi Ekonomi $\left(\mathrm{X}_{2}\right)$ & 0,490 & 2,041 \\
Lingkungan Keluarga $\left(\mathrm{X}_{3}\right)$ & 0,718 & 1,393 \\
Persepsi Biaya Pendidikan $\left(\mathrm{X}_{4}\right)$ & 0,641 & 1,560 \\
\hline
\end{tabular}

Sumber: Data Penelitian, 2019

Berdasarkan hasil analisis Tabel 7, menunjukkan bahwa nilai tolerance untuk setiap variabel motivasi karir, motivasi ekonomi, lingkungan keluarga, persepsi biaya pendidikan lebih besar dari 0,10 dan nilai VIF lebih kecil dari 10 yang berarti model persamaan regresi bebas dari gejela multikoloneritas.

\section{Tabel 8. Hasil Uji Heteroskedastisitas}

\begin{tabular}{ll}
\hline Model & Sig. \\
\hline Motivasi Karir $\left(\mathrm{X}_{1}\right)$ & 0,529 \\
Motivasi Ekonomi $\left(\mathrm{X}_{2}\right)$ & 0,989 \\
Lingkungan Keluarga $\left(\mathrm{X}_{3}\right)$ & 0,303 \\
Persepsi Biaya Pendidikan $\left(\mathrm{X}_{4}\right)$ & 0,180 \\
\hline
\end{tabular}

Sumber: Data Penelitian, 2019 
Berdasarkan hasil analisis Tabel 8, menunjukkan bahwa tingkat signifikansi tiap variabel bebas lebih besar dari 0,05 sehingga model regresi terbebas dari heteroskedasitas.

Hasil uji memberikan hasil dimana diperoleh besarnya adjusted $\mathrm{R}^{2}$ (koefisien determinasi yang telah disesuaikan) adalah 0,705. Hasil ini menunjukkan bahwa pengaruh variabel motivasi karir $\left(\mathrm{X}_{1}\right)$, motivasi ekonomi $\left(X_{2}\right)$, lingkungan keluarga $\left(X_{3}\right)$, persepsi biaya pendidikan $\left(X_{4}\right)$ terhadap variabel minat mahasiswa mengikuti PPAk (Y) sebesar 70,5 persen dan sisanya 29,5 persen dipengaruhi oleh faktor-faktor lain di luar model penelitian. Hasil uji F (Ftest) menunjukkan bahwa nilai signifikansi P value 0,000 yang lebih kecil dari $\alpha=0,05$, ini berarti model yang digunakan pada penelitian ini adalah layak. Hal ini dapat dikatakan bahwa terdapat pengaruh yang signifikan antara motivasi karir, motivasi ekonomi, lingkungan keluarga, persepsi biaya pendidikan pada minat mahasiswa mengikuti PPAk.

Tabel 9. Hasil Uji Analisis Regresi Linear Berganda

\begin{tabular}{cccccc}
\hline $\begin{array}{c}\text { Variabel } \\
\text { Bebas }\end{array}$ & $\begin{array}{c}\text { Koefisien } \\
\text { Regresi }\end{array}$ & $\begin{array}{c}\text { Standar } \\
\text { Eror }\end{array}$ & t-hitung & Sig. & Keterangan \\
\hline Motivasi Karir $\left(\mathrm{X}_{1}\right)$ & 0,208 & 0,034 & 6,186 & 0,000 & $\mathrm{H}_{1}$ diterima \\
$\begin{array}{c}\text { Motivasi Ekonomi }\left(\mathrm{X}_{2}\right) \\
\text { Lingkungan keluarga }\end{array}$ & 0,096 & 0,033 & 2,890 & 0,004 & $\mathrm{H}_{2}$ diterima \\
$\begin{array}{c}\left(\mathrm{X}_{3}\right) \\
\text { Persepsi Biaya }\end{array}$ & 0,104 & 0,050 & 2,093 & 0,038 & $\mathrm{H}_{3}$ diterima \\
$\begin{array}{c}\text { Pendidikan }\left(\mathrm{X}_{4}\right) \\
\text { Constant } \quad 0,237\end{array}$ & 0,030 & 7,814 & 0,000 & $\mathrm{H}_{4}$ diterima \\
Adjusted $\mathrm{R}^{2}=0,705$ & & F-hitung & $=108,661$ & \\
\end{tabular}

Sumber: Data Penelitian, 2019

Hipotesis pertama $\left(\mathrm{H}_{1}\right)$ menyatakan semakin tinggi motivasi karir mahasiswa jurusan akuntansi menyebabkan semakin tinggi minat mengikuti PPAk. Hasil uji statitsik menunjukkan bahwa $\mathrm{H}_{1}$ diterima, artinya semakin kuat motivasi mahasiswa dalam meningkatkan kemampuan pribadi dalam memperoleh karir yang baik, maka semakin tinggi minat mahasiswa dalam mengikuti pendidikan profesi akuntansi. Hal ini berarti semakin kuat keinginan seseorang untuk meniti karir maka semakin berminat seseorang untuk mengikuti Pendidikan Profesi Akuntansi (PPAk).

Penelitian ini sesuai dengan penelitian yang dilakukan Dyastari \& Yadnyana (2016), Vesperalis \& Muliartha (2017), serta Bagus \& Marta (2018) menunjukkan bahwa motivasi karir berpengaruh positif pada minat mahasiswa mengikuti Pendidikan Profesi Akuntansi (PPAk). Hal ini didukung oleh teori yang dikemukakan oleh Abraham Maslow pada salah satu point dari 5 hirarki yang telah dikemukakan yaitu kebutuhan pengahargaan (esteem needs), yaitu kebutuhan akan penghargaan atas prestasi yang telah diraih, kebutuhan akan rasa hormat dan pengakuaan atas kemampuan dan keahlian yang dimiliki, serta kebutuhan akan status kedudukan.

Hipotesis kedua $\left(\mathrm{H}_{2}\right)$ menyatakan semakin tinggi motivasi ekonomi mahasiswa jurusan akuntansi menyebabkan semakin tinggi minat mahasiswa mengikuti PPAk. Hasil uji statistik menunjukkan bahwa $\mathrm{H}_{2}$ diterima, artinya semakin kuat dorongan motivasi ekonomi mahasiswa untuk mencapai 
pengahargaan finansial yang diinginkan maka semakin tinggi minat mahasiswa mengikuti Pendidikan Profesi Akuntansi (PPAk). Hal ini berarti semakin kuat keinginan seseorang untuk meningkatkan kemampuan pribadinya dalam mencapai finansial yang diinginkan makan semakin berminat seseorang untuk mengikuti Pendidikan Profesi Akuntansi (PPAk).

Penelitian ini sesuai dengan penelitian yang dilakukan Berlinasari \& Erawati (2017), Dewi (2019), Saputra \& Kustina (2019) serta Bagus \& Marta (2018) menunjukkan bahwa motivasi ekenomi berpengaruh positif pada minat mahasiwa mengikuti pendidikan profesi akuntansi. Temuan penelitian ini sejalan dengan teori yang dikemukakan oleh Abraham Maslow yaitu kebutuhan fisiologis (phylogical needs), yang menyatakan bahwa kebutuhan yang paling dasar (fisik), seperti kebutuhan untuk memuaskan rasa lapar dan haus, kebutuhan akan perumahan (tempat tinggal), kebutuhan akan pakaian, dan sebagainya.

Hipotesis ketiga $\left(\mathrm{H}_{3}\right)$ menyatakan semakin tinggi dukungan dari lingkungan keluarga kepada mahasiswa jurusan akuntansi menyebabkan semakin tinggi minat mahasiswa mengikuti PPAk. Hasil uji statistik menunjukkan bahwa $\mathrm{H}_{3}$ diterima, artinya semakin besar dukungan dari lingkungan keluarga kepada mahasiswa maka semakin tinggi minat mahasiswa mengikuti Pendidikan Profesi Akuntansi (PPAk). Hal ini berarti semakin kuat adanya dorongan dari lingkungan keluarga dalam memberikan pandangan mengenai nilai-nilai dalam memilih pekerjaan, maka semakin berminat seseorang untuk mengikuti Pendidikan Profesi Akuntansi (PPAk).

Penelitian ini sesuai dengan yang dilakukan oleh Dibabe et al. (2015), Kurniawan et al. (2018), Hsiao \& De Castro Casa Nova (2016), Li \& Qiu (2018) menunjukkan bahwa lingkungan keluarga berpengaruh positif pada minat mahasiwa mengikuti pendidikan profesi akuntansi. Temuan penelitian ini sejalan dengan teori yang dikemukakan oleh Abraham Maslow yaitu Kebutuhan sosial (social needs), yang menyatakan kebutuhan akan rasa cinta dan kepuasan dalam menjalani hubungan dengan orang lain, kebutuhan akan kepuasan dan perasaan memiliki serta diterima dalam suatu kelompok, rasa kekeluargaan, persahabatan, dan kasih sayang.

Hipotesis keempat $\left(\mathrm{H}_{4}\right)$ menyatakan semakin tinggi persepsi positif mahasiswa jurusan akuntansi mengenai biaya pendidikan maka semakin tinggi minat mahasiswa mengikuti PPAk. Hasil uji statistik menunjukkan bahwa $\mathrm{H}_{4}$ diterima, artinya semakin tinggi persepsi positif mengenai cara pandang terhadap biaya pendidikan yang dikeluarkan oleh mahasiswa maka akan timbul minat mahasiswa mengikuti Pendidikan Profesi Akuntansi. Penelitian ini sesuai dengan yang dilakukan oleh Dewi \& Ratnadi (2018) persepsi biaya pendidikan berpengaruh positif pada minat mahasiswa mengikuti pendidikan profesi akuntansi. Hukum ekonomi menyatakan bahwa manusia ingin mendapatkan keuntungan yang setinggi-tingginya dengan biaya serendah-rendahnya. Biaya pendidikan tidak hanya dinilai dari sisi mahal tidaknya, tetapi dapat dilihat dari sisi bagaimana kemampuan mempersiapkan serta merasakan biaya yang dikeluarkan dihubungankan dengan kelayakan, kemudahan, dan kepatuhan dalam mengaskes perguruan tinggi tertentu (Aryani \& Erawati, 2016). 
Hasil penelitian ini diharapkan dapat memberikan kontribsusi mengenai pengaruh motivasi karir, motivasi ekonomi, lingkungan keluarga dan persepsi biaya pendidikan mengenai minat mahasiswa mengikuti Pendidikan Profesi Akuntansi. Hasil uji penelitian ini ditemukan bahwa motivasi karir, motivasi ekonomi, lingkungan keluarga, dan persepsi biaya pendidikan menunjukkan arah positif terhadap minat mahasiswa untuk mengikuti Pendidikan Profesi Akuntansi. Secara teoritis penelitian ini juga memberikan pemahaman bahwa motivasi karir, motivasi ekonomi, lingkungan keluarga, dan persepsi biaya pendidikan dapat mendorong mahasiswa untuk mengikuti Pendidikan Profesi Akuntansi dalam mencapai gelar akuntan secara profesional.

Hal ini juga didukung oleh teori motivasi Maslow yang menyatakan minat untuk mengetahui faktor yang memotivasi seseorang dan teori kebutuhan McClelland yang menyatakan bahwa kebutuhan seseorang untuk mendapatkan kepuasan. Dengan teori motivasi Maslow menjelaskan bahwa akan memberikan penalaran mengenai motivasi yang mendasari seseorang untuk bertindak dalam tingkatan yang berbeda dari kebutuhan seseorang. Teori Motivasi Maslow juga merupakan faktor yang memotivasi mahasiswa dalam mengikuti Pendidikan Profesi Akuntansi. Penelitian ini juga dapat dijadikan referensi konseptual serta perbandingan pengembangan dan penyempurnaan dari penelitian terdahulu.

Penelitian ini memberikan implikasi masukan atau pertimbangan bagi Fakultas Ekonomi dan Binis Universitas Udayana dalam proses kegiatan belajar mengajar terkait dengan mendorong minat mahasiswa untuk mengikuti Pendidikan Profesi Akuntansi. Organisasi juga dapat mengevaluasi dan meningkatkan motivasi karir, motivasi ekonomi, lingkungan keluarga, dan persepsi biaya pendidikan bagi mahasiswa karena hal tersebutt dapat mempengaruhi minat mahasiswa mengikuti pendidikan Profesi Akuntansi.

\section{SIMPULAN}

Motivasi karir berpengaruh postif pada minat mahasiswa jurusan akuntansi mengikuti Pendidikan Profesi Akuntansi. Hal ini menunjukkan bahwa semakin tinggi dorongan untuk meningkatkan kemampuan pribadi demi mencapai kedudukan, jabatan, atau karir yang lebih baik menyebabkan minat mengikuti PPAk semakin tinggi. Motivasi ekonomi berpengaruh positif pada minat mahasiswa akuntansi mengikuti Pendidikan Profesi Akuntansi. Hal ini menunjukkan bahwa semakin tinggi keinginan mahasiswa akuntansi dalam upaya meningkatkan kemampuan finansial yang ingin dicapai menyebabkan minat mengikuti PPAk semakin tinggi. Lingkungan keluarga berpengaruh positif pada minat mahasiswa akuntansi mengikuti Pendidikan Profesi Akuntansi. Hal ini menunjukkan bahwa semakin tinggi dorongan dari lingkungan keluarga terhadap mahasiswa menyebabkan minat mengikuti PPAk semakin tinggi. Persepsi biaya pendidikan berpengaruh positif mahasiswa jurusan akuntansi mengikuti Pendidikan Profesi Akuntansi. Hal ini menunjukan bahwa semakin tinggi persepsi positif mengenai biaya selama menempuh pendidikan yang dikeluarkan demi mendapatkan manfaat di masa depan menyebabkan minat mengikuti PPAk semakin tinggi.

Bagi program Pendidikan Profesi Akuntansi agar bisa lebih mensosialisasikan tujuan dari mengikuti PPAk dan diharapkan pada pihak 
penyelenggara PPAk untuk mengembangkan kurikulum dan fasilitasnya karena dalam penelitian ini, minat lulusan S1 untuk mengikuti PPAk masih relatif rendah. Program PPAk diharapkan juga diharapkan dapat memberikan pengetahuan lebih luas tentang profesi akuntansi kepada mahasiswa agar lebih banyak mahasiswa yang tertarik untuk mengikuti PPAk sebagai tahapan untuk menjadi akuntan profesional.

\section{REFERENSI}

Abdul Aziz, D., Ibrahim, M. A., Jaafar Sidik, M. H., \& Tajuddin, M. (2017). Accounting Students' Perception and Their Intention to Become Professionally Qualified Accountants. SHS Web of Conferences, 36, 00008. https://doi.org/10.1051/shsconf/20173600008

Aryani, N., \& Erawati, N. (2016). Pengaruh Motivasi Kualitas, Karir, Ekonomi, Dan Biaya Pendidikan Pada Minat Mahasiswa Mengikuti Pendidikan Profesi Akuntansi. E-Jurnal Akuntansi, 16(1), 362-387.

Bagus, I. M., \& Marta, A. (2018). Pengaruh Motivasi Kualitas, Motivasi Karir, Motivasi Ekonomi, Motivasi Sosial , Biaya Pendidikan pada Minat Mengikuti PPAk. 25, 214-240.

Baliyan, P. S., \& Baliyan, S. P. (2016). Employment Preference of Undergraduate Accounting Students in Botswana: Perceptional Analysis of Practitioners and Students. International Journal of Business and Management, 11(12), 271. https://doi.org/10.5539/ijbm.v11n12p271

Berlinasari, M., \& Erawati, N. M. A. (2017). Pengaruh Motivasi, Biaya Pendidikan dan Lama Pendidikan Pada Minat Mahasiswa Akuntansi Mengikuti PPAk. E-Jurnal Akuntansi Universitas Udayana, 21(1), 447-476.

Chaudhary, G. K. (2015). Factors affecting curriculum implementation for students. International Journal of Applied Research, 1(12), 984-986. Retrieved from www.allresearchjournal.com

Dewi, A. (2019). Pengaruh Sikap dan Motivasi terhadap Minat Mahasiswa untuk Mengikuti Pendidikan Profesi Akuntan ( PPAk ). E-Jurnal Akuntansi Universitas Udayana, 27(1), 1678-1702.

Dewi dan Ratnadi. (2018). Pengaruh Motivasi , Biaya, dan Pengetahuan Mahasiswa Tentang UU No . 5 Tahun 2011 Pada Minat PPAk. 22(5), 51-79.

Dibabe, T. M., Wubie, A. W., \& Wondmagegn, G. A. (2015). Factors that Affect Students ' Career Choice in Accounting: A Case of Bahir Dar University Students. Research Journal of Finance and Accounting, 6(5), 146-154.

Dos Santos, E. A., \& De Almeida, L. B. (2018). Seguir ou não carreira na área de contabilidade: Um estudo sob o enfoque da Teoria do Comportamento Planejado. Revista Contabilidade e Financas, 29(76), 114-128. https://doi.org/10.1590/1808-057x201804890

Dyastari, N., \& Yadnyana, I. (2016). Pengaruh Motivasi Pada Minat Mahasiswa Non Akuntansi Untuk Mengikuti Pendidikan Profesi Akuntansi. E-Jurnal Akuntansi, 16(1), 333-361.

Giantari, N. Lu. dan R. I. W. (2019). Pengaruh Motivasi, Lingkungan Keluarga dan Pendidikan Terhadap Minat Berwirausaha Mahasiswa Jurusan Akuntansi Reguler. E-Jurnal Akuntansi, 28(2302-8556), 1-25.

Hsiao, J., \& De Castro Casa Nova, S. P. (2016). Generational approach to factors 
influencing career choice in accounting. Revista Contabilidade e Financas, 27(72), 393-407. https://doi.org/10.1590/1808-057x201602980

Ikbal, M. (2015). Pengaruh Motivasi terhadap Minat Mahasiswa Akuntansi untuk Mengikuti Pendidikan Profesi Akuntansi (Ppak). Jurnal Online Mahasiswa Fakultas Ekonomi Universitas Riau, 1(1).

Khomsiyah, \& Lindrianasari. (2017). The influence of accounting education on the prospects of becoming a member of the chartered accountant profession: Opportunities, challenges and expectations of Indonesia towards the ASEAN economic community. International Journal of Monetary Economics and Finance, 10(3-4), 257-269. https://doi.org/10.1504/IJMEF.2017.087482

Kurniawan, J., Effendi, Z. M., \& Dwita, S. (2018). The Effect of School Environment, Family Environment and Learning Motivation on Studentsr Learning Performance. Advances in Economics, Business and Management Research, 57(Piceeba), 571-576. https://doi.org/10.2991/piceeba-18.2018.6

Li, Z., \& Qiu, Z. (2018). How does family background affect children's educational achievement? Evidence from Contemporary China. Journal of Chinese Sociology, 5(1), 1-20. https://doi.org/10.1186/s40711-018-0083-8

Made, A. A., Adelia, C., Putu, A. A., Widanaputra, G., Putu, N., \& Harta, S. (2020). Influence Career Motivation, Perception Cost of Education and Length of Education on the Interest of Students Following Education Master of Accounting. International Journal of Management and Commerce Innovations ISSN, 7(2), 605-611.

Mbawuni, J., \& Nimako, S. G. (2015). Modelling Job-related and Personality Predictors of Intention to Pursue Accounting Careers among Undergraduate Students in Ghana. World Journal of Education, 5(1), 65-81. https://doi.org/10.5430/wje.v5n1p65

Park, Y. H., Paik, T. Y., \& Koo, J. H. (2019). Effect of student activity participation on accounting education. Journal of Open Innovation: Technology, Market, and Complexity, 5(3), 1-11. https://doi.org/10.3390/JOITMC5030040

Rosyadi, R. I. (2018). Analysis of Factors that Influence the Interest of Accounting Students Following Accounting Professional Education. International Summit on Science Technology and Humanity, 1(1), 310-318.

Rybnicek, R., Bergner, S., \& Gutschelhofer, A. (2019). How individual needs influence motivation effects: a neuroscientific study on McClelland's need theory. In Review of Managerial Science (Vol. 13). https://doi.org/10.1007/s11846-017-0252-1

Sapitri, Z., \& Yaya, R. (2015). Faktor-Faktor Yang Berpengaruh Terhadap Minat Mahasiswa Untuk Mengikuti Pendidikan Profesi Akuntansi (PPAk). Jurnal Akuntansi \& Investasi, 16(1), 46-61.

Saputra, R., \& Kustina, K. T. (2019). Minat Mahasiswa Akuntansi Untuk Mengikuti Pendidikan Profesi. Jurnal Ilmiah Akuntansi \& Bisnis, 4(1), 73-80.

Sigry. (2015). Is Materialism All That Bad? Effects on Satisfaction with Material Life; Life Satisfaction, and Economic Motivation. Social Indicators Research, 110, 10-14. https://doi.org/10.16194/j.cnki.31-1059/g4.2015.07.016

Sojow, L., Wajong, A., \& Sangi, N. (2018). Vocational Students' Motivation for Professional Skills. IOP Conference Series: Materials Science and Engineering, 306(1), 1-12. https://doi.org/10.1088/1757-899X/306/1/012072 
Vesperalis, A. A. A. D., \& Muliartha, K. R. (2017). Pengaruh Motivasi pada Minat Sarjana Akuntansi Universitas Udayana untuk Mengikuti PPAk. E-Jurnal Akuntansi Universitas Udayana, 19(2), 1691-1718. 